\title{
Effects of Alcohol Consumption on HDL Metabolism in Asian Populations
}

\author{
Hidekatsu Yanai ${ }^{\mathrm{a}, \mathrm{c}}$, Hisayuki Katsuyama ${ }^{\mathrm{a}}$, Hidetaka Hamasaki ${ }^{\mathrm{a}}$, \\ Shinichi Abe ${ }^{\mathrm{b}}$, Norio Tada ${ }^{\mathrm{b}}$, Akahito Sako ${ }^{\mathrm{a}}$
}

\begin{abstract}
Low serum high-density lipoprotein-cholesterol (HDL-C) is an independent coronary risk factor, because HDL acts to mediate the uptake of peripheral cholesterol and return it to the liver. Therefore, raising HDL-C may be one of the goals in the management of atherogenic dyslipidemia for cardiovascular disease risk reduction. Although lifestyle modification such as diet and exercise may be important to increase HDL-C, effects of dietary factors on HDL-C remained largely unknown. Interracial differences on HDL metabolism may exist. Here we reviewed published articles about effect of alcohol consumption on HDL metabolism in Asian populations, regarding systematic review and meta-analysis and also clinical studies performed in Asian populations as important articles in this review.
\end{abstract}

Keywords: Alcohol consumption; Asian population; High-density lipoprotein; Meta-analysis

\section{Introduction}

The treatment of atherogenic dyslipidemia generally has focused on low-density lipoprotein-cholesterol (LDL-C) reduction to reduce cardiovascular diseases (CVDs). Even though the statin use has significantly reduced cardiovascular events, $15-30 \%$ of patients still continue to have CVDs

Manuscript accepted for publication April 25, 2014

${ }^{a}$ Department of Internal Medicine, National Center for Global Health and Medicine Kohnodai Hospital, Chiba, Japan

${ }^{\mathrm{b}}$ The Jikei University School of Medicine, Tokyo, Japan

${ }^{\mathrm{c}}$ Corresponding author: Hidekatsu Yanai, Department of Internal

Medicine, National Center for Global Health and Medicine Kohnodai

Hospital, 1-7-1 Kohnodai, Chiba 272-8516, Japan.

Email: dyanai@hospk.ncgm.go.jp

doi: http://dx.doi.org/10.14740/jem217w
[1]. Low serum high-density lipoprotein-cholesterol (HDL$\mathrm{C}$ ) is an independent coronary risk factor [2], and is also one of the defining features of metabolic syndrome [3]. HDL acts to mediate the uptake of peripheral cholesterol and return it to the liver, which may be the main mechanism for antiatherogenic property of HDL.

Therefore, raising HDL-C may be one of the goals in the management of atherogenic dyslipidemia for CVD risk reduction. Although lifestyle modification such as diet and exercise may be important to increase HDL-C, effects of dietary factors on HDL-C remained largely unknown. Interracial differences on HDL metabolism may exist. Here we reviewed published articles about effect of alcohol consumption on HDL metabolism in Asian populations. We regarded systematic review and meta-analysis and also clinical studies which were performed in Asian populations as important articles in this review.

\section{Meta-Analyses and Systematic Reviews on Ef- fects of Alcohol Consumption on HDL Metabo- lism}

Light-to-moderate alcohol consumption has been reported to induce an increase of HDL-C in narrative reviews. However, evidences obtained from meta-analyses or systematic reviews of effects of alcohol consumption on HDL metabolism were very limited (Table 1).

Brien et al systematically reviewed interventional studies of the effects of alcohol consumption on biological markers in adults without known CVD [4]. Data sources were Medline (1950 to October 2009) and Embase (1980 to October 2009). They found that alcohol consumption significantly increased HDL-C (pooled mean difference $0.094 \mathrm{mmol} / \mathrm{L}$, $95 \%$ confidence interval 0.064 to 0.123 ), and the major apolipoprotein of HDL, apolipoprotein A1 $(0.101 \mathrm{~g} / \mathrm{L}, 0.073$ to $0.129)$. In their study, alcohol showed a dose-response relation with HDL-C $(\mathrm{P}=0.013)$.

Rimm et al also performed a meta-analysis of all clinical studies that assessed the effects of moderate alcohol intake on coronary risk factors [5]. Subjects included men and women free of previous chronic disease and who were not dependent 
Table 1. Meta-Analysis and Systematic Review of Effects of Alcohol Consumption on HDL Metabolism

\begin{tabular}{|c|c|c|c|}
\hline Authors & $\begin{array}{l}\text { Aim of study and study } \\
\text { design }\end{array}$ & Subjects studied & Results/conclusions \\
\hline Brien et al [4] & $\begin{array}{l}\text { To systematically } \\
\text { review interventional } \\
\text { studies of the effects of } \\
\text { alcohol consumption on } \\
21 \text { biological markers } \\
\text { associated with coronary } \\
\text { risk factors in adults } \\
\text { without known CVD. }\end{array}$ & $\begin{array}{l}\text { Data sources: Medline } \\
\text { (1950 to October } 2009) \\
\text { and Embase (1980 to } \\
\text { October 2009) without } \\
\text { limits. }\end{array}$ & $\begin{array}{l}\text { Alcohol significantly } \\
\text { increased HDL-C (pooled } \\
\text { mean difference } 0.094 \\
\text { mmol/L, } 95 \% \text { CI } 0.064 \text { to } \\
0.123) \text {. Alcohol showed a } \\
\text { dose-response relation with } \\
\text { HDL-C }(\mathrm{P}=0.013) \text {. }\end{array}$ \\
\hline Rimm et al [5] & $\begin{array}{l}\text { Meta-analysis of all } \\
\text { experimental studies that } \\
\text { assessed the effects of } \\
\text { moderate alcohol intake } \\
\text { on coronary risk factors. }\end{array}$ & $\begin{array}{l}\text { Sixty-one data records } \\
\text { were abstracted from } 42 \\
\text { eligible studies. Men and } \\
\text { women free of chronic } \\
\text { disease and who were not } \\
\text { dependent on alcohol. } \\
\text { Coronary risk factors } \\
\text { were assessed before } \\
\text { and after participants } \\
\text { consumed up to } 100 \mathrm{~g} \text { of } \\
\text { alcohol a day. }\end{array}$ & $\begin{array}{l}\text { An experimental dose } \\
\text { of } 30 \mathrm{~g} \text { of ethanol a day } \\
\text { increased HDL-C by } 3.99 \\
\mathrm{mg} / \mathrm{dL}(95 \% \text { CI } 3.25 \text { to } \\
4.73) \text {. }\end{array}$ \\
\hline
\end{tabular}

CVD: cardiovascular disease; Cl: confidence interval; HDL-C: high-density lipoprotein-cholesterol.

on alcohol. Studies were included in which biomarkers were assessed before and after participants consumed up to $100 \mathrm{~g}$ of alcohol a day. Sixty-one data records were abstracted from 42 eligible studies. An experimental dose of $30 \mathrm{~g}$ of ethanol a day increased HDL-C by $3.99 \mathrm{mg} / \mathrm{dL}$ (95\% confidence interval 3.25 to 4.73 ) and also apolipoprotein A1 by $8.82 \mathrm{mg} /$ dL (7.79 to 9.86$)$.

According to the results obtained from a meta-analysis and systematic review, alcohol consumption is associated with elevation of HDL and also apolipoprotein A1.

\section{Clinical Trials to Study Effects of Alcohol Con- sumption on HDL Metabolism, Performed in Asian Populations}

Clinical trials to study effects of alcohol consumption on HDL-C, performed in Asian populations, were shown in Table 2 . Chung et al performed a cross-sectional communitybased study to investigate the influence of alcohol consumption on biomarkers in a Southern Taiwan Pai-Wan aboriginal community with a high prevalence of alcohol consumption [6]. They found that subjects with alcohol consumption had significantly higher levels of HDL-C than non-drinkers. Minami et al investigated the effect of alcohol restriction on metabolic variables in Japanese men [7]. Thirty-three male subjects $(37 \pm 1$ years) who habitually drank alcohol (646 $\mathrm{mL}$ of ethanol/day) were told either to keep their usual drinking habits for 3 weeks, or to reduce alcohol intake by at least up to a half of their usual drinking amount, by using a randomized crossover design. Three-week alcohol restriction significantly decreased serum HDL-C $(\mathrm{P}<0.05)$. Ayaori et al performed a population-based study and an alcohol withdrawal study [8]. An analysis of 236 healthy males showed no significant association between alcohol consumption and HDL-C. In the withdrawal study, the subjects with a history of daily alcohol consumption (mean $\pm \mathrm{SD}, 81.8 \pm 33.0 \mathrm{~g} /$ day; range, 40 - $150 \mathrm{~g} /$ day) abstained from alcohol for 4 weeks. After withdrawal, HDL-C significantly decreased. Kato et al performed a cross-sectional analysis in 2,103 non-diabetic men and women aged 40 to 79 years from a general Japanese population in Hisayama [9]. In both sexes, HDL-C significantly increased with elevated alcohol intake $(\mathrm{P}<0.01)$. Yano et al investigated cross-sectionally in a random sample of approximately 1,360 elderly Japanese men, aged $60-81$ years, in Hawaii. In multivariate analyses, HDL-C was positively related to alcohol consumption $(\mathrm{P}<0.0001)[10]$.

According to the results of clinical trials to study effects of alcohol consumption on HDL-C, alcohol consumption is associated with elevation of HDL-C in Asian population. 
Table 2. Clinical Trials to Study Effects of Alcohol Consumption on HDL-C, Performed in Asian Populations

\begin{tabular}{|c|c|c|c|c|}
\hline Authors & $\begin{array}{l}\text { Nationality of } \\
\text { subjects }\end{array}$ & Subjects studied & Study design & Results/conclusions \\
\hline Chung et al [6] & Taiwanese & $\begin{array}{l}\text { The 1,466 aboriginal } \\
\text { subjects, } 40 \text { - } 95 \text { years } \\
\text { of age, are a stratified } \\
\text { random subpopulation } \\
\text { identified during an } \\
\text { integrative health care } \\
\text { program. }\end{array}$ & $\begin{array}{l}\text { A cross-sectional } \\
\text { community-based } \\
\text { study. They were } \\
\text { sampled for drinking } \\
\text { patterns. }\end{array}$ & $\begin{array}{l}\text { Subjects with alcohol } \\
\text { consumption had } \\
\text { significantly higher levels } \\
\text { of serum HDL-C. }\end{array}$ \\
\hline $\begin{array}{l}\text { Minami et al } \\
{[7]}\end{array}$ & Japanese & $\begin{array}{l}\text { Thirty-three male } \\
\text { subjects ( } 37 \pm 1 \\
\text { years) who habitually } \\
\text { drank alcohol ( } 646 \\
\text { mL of ethanlol/day). }\end{array}$ & $\begin{array}{l}\text { Thirty-three male } \\
\text { subjects ( } 37 \pm 1 \text { years) } \\
\text { who habitually drank } \\
\text { alcohol ( } 646 \mathrm{~mL} \text { of } \\
\text { ethanlol/day) were } \\
\text { told either to keep } \\
\text { their usual drinking } \\
\text { habits for } 3 \text { weeks, } \\
\text { or to reduce alcohol } \\
\text { intake by at least up } \\
\text { to a half of their usual } \\
\text { drinking amount using } \\
\text { a randomized crossover } \\
\text { design. }\end{array}$ & $\begin{array}{l}\text { Three-week alcohol } \\
\text { restriction significantly } \\
\text { serum HDL-C decreased } \\
(\mathrm{P}<0.05)\end{array}$ \\
\hline Ayaori et al [8] & Japanese & $\begin{array}{l}\text { Two hundred thirty- } \\
\text { six healthy males and } \\
\text { in the withdrawal } \\
\text { study, the subjects } \\
\text { with a history of daily } \\
\text { alcohol consumption } \\
\text { (mean } \pm \mathrm{SD}, 81.8 \pm \\
33.0 \mathrm{~g} / \text { day; range, } 40 \\
\text { - } 150 \mathrm{~g} / \text { day). }\end{array}$ & $\begin{array}{l}\text { A population-based } \\
\text { study and an alcohol } \\
\text { withdrawal study. }\end{array}$ & $\begin{array}{l}\text { Two hundred thirty- } \\
\text { six healthy males } \\
\text { showed no significant } \\
\text { association between } \\
\text { alcohol consumption and } \\
\text { metabolic parameters. } \\
\text { In the withdrawal study, } \\
\text { the subjects with a } \\
\text { history of daily alcohol } \\
\text { consumption abstained } \\
\text { from alcohol for } 4 \text { weeks. } \\
\text { After withdrawal, HDL-C } \\
\text { significantly decreased. }\end{array}$ \\
\hline Kato et al [9] & Japanese & $\begin{array}{l}\text { Two thousand one } \\
\text { hundred three non- } \\
\text { diabetic men and } \\
\text { women aged } 40 \text { to } 79 \\
\text { years from a general } \\
\text { Japanese population. }\end{array}$ & $\begin{array}{l}\text { A cross-sectional study } \\
\text { to determine whether } \\
\text { the beneficial effects of } \\
\text { alcohol on serum lipids } \\
\text { are mediated by insulin } \\
\text { levels. }\end{array}$ & $\begin{array}{l}\text { In both sexes, HDL-C } \\
\text { significantly increased } \\
\text { with elevated alcohol } \\
\text { intake. }\end{array}$ \\
\hline Yano et al [10] & $\begin{array}{l}\text { Japanese in } \\
\text { Hawaii }\end{array}$ & $\begin{array}{l}\text { Approximately } 1,360 \\
\text { elderly Japanese men, } \\
\text { aged } 60 \text { - } 81 \text { years, in } \\
\text { Hawaii, USA. }\end{array}$ & $\begin{array}{l}\text { The relationships of } \\
\text { plasma TC, HDL-C, } \\
\text { LDL-C and TG to a } \\
\text { variety of personal } \\
\text { attributes were } \\
\text { investigated cross- } \\
\text { sectionally in a random } \\
\text { sample. }\end{array}$ & $\begin{array}{l}\text { HDL-C was positively } \\
\text { related to alcohol } \\
\text { consumption }(\mathrm{P}< \\
0.0001) .\end{array}$ \\
\hline
\end{tabular}




\section{Conclusion}

The underlying mechanisms for alcohol-induced elevation of HDL-C remain largely unknown. Alcohol-induced increase in activity of lipoprotein lipase which transfers of cholesterol and phospholipids from triglyceride-rich lipoproteins to HDL during the lipolysis may be a possible explanation for HDL-C increase due to alcohol consumption $[11,12]$.

According to the results obtained from a meta-analysis and systematic review, and also clinical trials performed in Asian population, alcohol consumption may be associated with elevation of HDL-C.

\section{Acknowledgement}

This work was supported by a grant from the National Center for Global Health and Medicine (25-203).

\section{Conflict of Interests}

The authors declare that they have no competing interests.

\section{References}

1. Bhatt KN, Wells BJ, Sperling LS, Baer JT. High-density lipoprotein therapy: is there hope? Curr Treat Options Cardiovasc Med. 2010;12(4):315-328.

2. Brewer HB, Jr. Clinical review: The evolving role of HDL in the treatment of high-risk patients with cardiovascular disease. J Clin Endocrinol Metab. 2011;96(5):1246-1257.

3. Singh V, Sharma R, Kumar A, Deedwania P. Low highdensity lipoprotein cholesterol: current status and future strategies for management. Vasc Health Risk Manag. 2010;6:979-996.

4. Brien SE, Ronksley PE, Turner BJ, Mukamal KJ, Ghali WA. Effect of alcohol consumption on biological mark- ers associated with risk of coronary heart disease: systematic review and meta-analysis of interventional studies. BMJ. 2011;342:d636.

5. Rimm EB, Williams P, Fosher K, Criqui M, Stampfer MJ. Moderate alcohol intake and lower risk of coronary heart disease: meta-analysis of effects on lipids and haemostatic factors. BMJ. 1999;319(7224):1523-1528.

6. Chung FM, Yang YH, Shieh TY, Shin SJ, Tsai JC, Lee YJ. Effect of alcohol consumption on estimated glomerular filtration rate and creatinine clearance rate. Nephrol Dial Transplant. 2005;20(8):1610-1616.

7. Minami J, Todoroki M, Yoshii M, Mita S, Nishikimi T, Ishimitsu T, Matsuoka H. Effects of smoking cessation or alcohol restriction on metabolic and fibrinolytic variables in Japanese men. Clin Sci (Lond). 2002;103(2):117-122.

8. Ayaori M, Hisada T, Yoshida H, Shige H, Ito T, Nakajima K, Higashi K, et al. Effect of alcohol intake on the levels of plasma homocysteine in healthy males. J Nutr Sci Vitaminol (Tokyo). 2000;46(4):171-174.

9. Kato I, Kiyohara Y, Kubo M, Tanizaki Y, Arima H, Iwamoto $\mathrm{H}$, Shinohara $\mathrm{N}$, et al. Insulin-mediated effects of alcohol intake on serum lipid levels in a general population: the Hisayama Study. J Clin Epidemiol. 2003;56(2):196-204.

10. Yano K, Reed DM, Curb JD, Hankin JH, Albers JJ. Biological and dietary correlates of plasma lipids and lipoproteins among elderly Japanese men in Hawaii. Arteriosclerosis. 1986;6(4):422-433.

11. Schneider J, Liesenfeld A, Mordasini R, Schubotz R, Zofel P, Kubel F, Vandre-Plozzitzka C, et al. Lipoprotein fractions, lipoprotein lipase and hepatic triglyceride lipase during short-term and long-term uptake of ethanol in healthy subjects. Atherosclerosis. 1985;57(2-3):281-291.

12. Nishiwaki M, Ishikawa $T$, Ito $T$, Shige $H$, Tomiyasu $K$, Nakajima K, Kondo K, et al. Effects of alcohol on lipoprotein lipase, hepatic lipase, cholesteryl ester transfer protein, and lecithin:cholesterol acyltransferase in highdensity lipoprotein cholesterol elevation. Atherosclerosis. 1994;111(1):99-109. 